\title{
Regina Lubas-Bartoszyńska
}

\section{Autobiografie filozofów}

\begin{abstract}
Lubas-Bartoszyńska Regina, Autobiografie filozofów [Autobiographies of philosophers]. „Przestrzenie Teorii" 13. Poznań 2010, Adam Mickiewicz University Press, pp. 55-75. ISBN 978-83-232-2176-0. ISSN 1644-6763.

The article Autobiographies of philosophers is composed of three parts. The first part presents the history of philosophic autobiography since antiquity and spiritual autobiography of Saint Augustine, through "Confessions" of J.J. Rousseau - the creator of modern autobiography, Pascal, G. Berkeley and S. Kierkegaard, back to "Ecce homo" of Nietzsche. The second part presents selected autobiographies of philosophers of the 20th century like an autobiography of B. Russell (three volumes), M. Bierdiaev, K. Jaspers. The third part is an interpretation of the intellectual autobiography of P. Ricoeur, in which the author reproduces history of intellectual and philosophic development and shows the dissimilarity of "idem" to his own identity.
\end{abstract}

\section{Część wstępna}

Refleksja nad sposobem wypełniania upływającego czasu własnym doświadczeniem życiowym, warunkowanym obecnością innych, wymaga głębszego namysłu, nie zawsze w pełni uświadomionego, nad ogólnymi zasadami wcielania mądrości i piękna życia w dany nam czas biologiczny. Ludzkość myślała o tym od wieków, skoro jednym ze źródeł filozofii według podręcznika historii filozofii Władysława Tatarkiewicza ${ }^{1}$ jest zespół reguł życiowych wyrosłych jako uogólnienie doświadczeń osobistych i publicznych (obok wierzeń religijnych i umiejętności praktycznych). Nic też dziwnego, że początki tekstowej narracji autobiograficznej (niemetaforycznych ujęć raju - zob. przyp. 12) wiążą się z pracami filozofów umiejących lepiej niż inni interpretować świat, który stał się opowieścią, a z własnej filozofii czynić historię do opowiedzenia. Oni też refleksją filozoficzną ogarniają istotę autobiografii, z jej perspektywy formułując definicję gatunku. Czynią to zarówno w obrębie dyskursu filozoficznego, jak i w ramach wypowiedzi metatekstowej własnych opowieści autobiograficznych.

Znamiennego przykładu tej dwutorowości refleksji nad autobiografią dostarczy nam schyłek wieku XX w osobie filozofa - hermeneuty, fenomenologa hermeneutycznego i filozofa człowieka - Paula Ricoeura², któ-

1 W. Tatarkiewicz, Historia filozofii, t. I: Starożytność $i$ średniowiecze, wyd. III, Czytelnik, Warszawa 1946, s. 11.

2 Takie trzy pola aktywności filozoficznej P. Ricoeura najogólniej zakreśla autor książki o tym filozofie - M. Drwięga, Paul Ricoeur daje do myślenia, wyd. Homini, Bydgoszcz 1998. 
ry zanim w sytuacji granicznej napisał swą autobiografię, rozważającą także problemy teoretyczne, pochylał się nad nią wcześniej w 3-tomowym dziele filozoficzno-strukturalistycznym (Temps et récit, 1983, 1984, 1991). Tu wiele uwagi poświęcił zagadnieniom referencji w ramach Mimesis III ${ }^{3}$ (a w tym obszarze mieści się także dyskurs historiozoficzny i autobiograficzny), formułował filozoficzną definicję autobiografii jako doświadczenia wewnętrznego, fenomenologicznego dochodzenia do prawdy o sobie, określenia swego miejsca wobec Boga 4 . Tu także oraz w książce (Soi-même comme un autre, 1990) stworzył Ricoeur kategorię przydatną szczególnie w pisaniu osobistym i w jego badaniu, którą pokazał wprost pod koniec swej autobiografii - „identité narrative”.

Biorąc pod uwagę całokształt teorii referencji, łącznie $\mathrm{z}$ modnym w ponowoczesności jej znoszeniem, przyjmujemy jednak, że „referent nie jest obiektem na zewnątrz, ale czymś, co należy sprowadzić z powrotem do wewnątrz dyskursu" $\mathrm{i}$ że jest on „sztucznie kreowany poprzez wymazanie wszystkich zabiegów mediacji”. Uważamy przeto, że Lejeune'ow-

3 Przegląd różnych stanowisk wobec referencji daje książka E. Bieńczyk pt. Obraz, który nas zniewala. Wspótczesne ujęcia języka wobec esencjalizmu i referencji, Universitas, Kraków 2007. Na potrzeby autobiografii istotne jest stwierdzenie J. Mitterera, odsłaniającego również dzieje koncepcji referencji, że dążenie do poznania i prawdy jest także dążeniem do nieodbiegania od rzeczywistości, od przedmiotów opisów albo od jakiegoś danego systemu twierdzeń. Zob. J. Mitterer, Tamta strona filozofii, przeł. M. Łukasiewicz, Terminus 9, Oficyna Nauk., Warszawa 1996, s. 75. Piszący o zmierzchu opowieści wychodzą z założenia, że „czas ludzki” to czas opowiadany, a refleksja nad nim i nad odkrywaną przez niego „rzeczy wielością” zmierza w efekcie - po licznych perturbacjach - ku referencji opowieści. Zob. O. Moregin, Zmierzch opowieści, [w:] Wiek dwudziesty przekroje, red. Yves Bertherat, „Esprit” Oficyna Literacka, Kraków 1991, s. 251.

${ }_{4}^{4}$ Zob. Z. Mitosek, Hermeneutyka i autobiografia, „Teksty Drugie” 2002, nr 3, s. 137-151.

${ }^{5}$ Na temat „identité narrative” i przydatności tej kategorii do badań nad „opowieścią autobiograficzną" - zob. D. Bertholet, Les Français par eux-mêmes 1815-1885, Paris 1991, „L'Introduction” i omówienia poszczególnych opowieści autobiograficznych wielkich twórców kultury francuskiej XIX wieku. W Polsce - skromny ślad pracy Bertholeta - zob. R. Lubas-Bartoszyńska, Sukcesy i gorycze: o „historiach życia” polityków polskiej opozycji antykomunistycznej, Wyd. Nauk. Akademii Pedagogicznej, Kraków 1998, s. 16-21 oraz omówienia poszczególnych „historii życia”. Zob. dalej - E. Mukoid, artykuł pt. Autobiographies philosophiques, Autobiographies des philosophes, w którym kategorię „identité narrative" odnosi do dzieł pięciu filozofów: św. Augustyna (Wyznania), Kartezjusza (Discours de la méthodes), Pascala (Myśli), Russella (Autobiografia, t. I i Mój rozwój filozoficzny), E. Stein (Autobiografia), Rocznik Naukowo-Dydaktyczny WSP w Krakowie 1994, s. 201208. Zob. też Z. Mitosek, Hermeneutyka i autobiografia, dz. cyt. Z perspektywy interdyscyplinarnej, neuropsychologii, antropologii kulturowej, literatury, lingwistyki kategorię „tożsamości narracyjnej” rozpatruje J. Kordys w książce Kategorie antropologiczne $i$ tożsamość narracyjna. Szkice $z$ pogranicza neurosemiotyki $i$ historii kultury, Universitas, Kraków 2007.

${ }^{6}$ E. Bińczyk, Obraz, który nas zniewala..., dz. cyt., s. 231.

7 Tamże. 
ski „pakt autobiograficzny” owe zabiegi mediacji ocala. Jest to „pakt prawdy", odwołujący się do referenta, ale poprzez narrację ocalający elementy autokreacji8.

$\mathrm{Z}$ tej racji przedmiotem uwagi niniejszego szkicu będą wypowiedzi autobiograficzne ludzi zapisanych $\mathrm{w}$ dziejach kultury jako filozofowie w pierwszym rzędzie; zwykle bowiem są oni także ludźmi drugiej, a czasem kolejnej profesji. Dlatego mimo silnego ufilozoficznienia pisarstwa antropologicznego i lingwistycznego Claude'a Lévi-Straussa i uznania go przez Przewodnik po literaturze filozoficznej XX wieku (t. I-V) ${ }^{9}$ za przedstawiciela literatury filozoficznej, jego Smutek tropików (1955), pamiętnik podróży etnograficznych badacza, czy silnie zautobiografizowane dzieło antropologiczne Myśl nieoswojona (1962) nie będą tu brane pod uwagę. To samo dotyczy kilku tekstów autobiograficznych antropologa, badacza religii - Mircei Eliadego ${ }^{10}$ czy wypowiedzi o charakterze autobiograficznym współtwórcy wielu nowych nurtów myślenia o kulturze Rolanda Barthes'a11 i wielu innych.

W pierwszej części tekstu dokonam przeglądu wypowiedzi autobiograficznych filozofów na przestrzeni wieków. Następnie przedstawię w wielkim skrócie ważniejsze autobiografie filozofów XX wieku, skupiając uwagę na jednej, wspomnianej wyżej Autobiografii intelektualnej Paula Ricoeura.

\section{Część I. Autobiografia filozoficzna poprzez wieki}

Historie autobiografii, choćby Autobiographie en France czy La découverte de soi i Les Écritures du moi Georges'a Gusdorfa ${ }^{12}$, G. Mischa A History of Autobiography in Antiquity ${ }^{13}$ już u starożytnych dostrzegają

8 P. Lejeune, Le pacte autobiographique, Seuil, Paris 1975. Wydanie polskie Pakt autobiograficzny, przeł. A. Labuda, [w:] Wariacje na temat pewnego paktu, red. R. Lubas-Bartoszyńska, Universitas, Kraków 2001, wyd. II 2007. Zob. też P. Lejeune, Signes de vie, Seuil, Paris 2005.

9 Przewodnik po literaturze filozoficznej XX wieku, t. I-V, red. B. Skarga, Wyd. PWN, Warszawa 1994-1997.

10 M. Eliade, Zapowiedź równonocy. Pamiętnik 1907-1937, t. I, wyd. pol. 1988; t. II Świętojańskie żniwo. Pamiętnik 1937-1960, wyd. pol. 1991; Dziennik indyjski. Moje życie, wyd. pol. 1999; Fragmenty Dziennika 1941-1985, wyd. pol. 2002; powieści autobiograficzne, np. Izabela $i$ woda diabła (1930), Powrót z raju (1934) i inne.

${ }^{11}$ Roland Barthes par Roland Barthes, Paris 1975; Carnet du voyage en Chine, Paris 2009, (IMEG); Journal de deuil, Paris 2009, (IMEG); zautobiografizowany esej Światto obrazu (La chambre claire), Paris 1980.

12 G. Gusdorf, La découverte de soi, Paris 1948; Les Écritures du moi, t. II: Autobiographie, t. I: Ligne de vie, ed. Odile Jacob, Paris 1990. Autor początki autobiografii wiąże $\mathrm{z}$ historią Adama i Ewy.

${ }^{13} \mathrm{G}$. Misch, A History of Autobiography in Antiquity, London 1950. 
zadatki pewnych form autobiografii, zwłaszcza autoportretu. „Popularne greckie zagadnienie, jak najlepiej żyć i osiągnąć dostępne człowiekowi dobra, czyli "eudajmonię« stało się teraz powszechnym zagadnieniem filozofów" - pisze o trzecim okresie filozofii greckiej Tatarkiewicz ${ }^{14}$. Zarówno cesarz i filozof Marek Aureliusz w Rozmyślaniach, jak i stoik Seneka dostarczają elementów autoportretu i pamiętnika w ramach wypowiedzi filozoficznej. Głośna dyskusja Gusdorfa z Lejeune’em na temat początków autobiografii dotyczy w gruncie rzeczy autobiografii dwu filozofów: św. Augustyna (też teologa) - V wiek n.e. i Jeana Jacques'a Rousseau (też pisarza) - wiek XVIII ${ }^{15}$. Wyznania św. Augustyna, ukazujące osobiste uwielbienie Boga, u swego końca - w ostatnich dwu księgach, zawierają też zarys własnej biografii teologa i filozofa w jednej osobie. Nowoczesną autobiografię natomiast zapoczątkowują dopiero Wyznania Jeana Jacques'a Rousseau. Wyznania św. Augustyna, należąc do nurtu pisania filozoficzno-moralno-mistycznego, otwierają też listę tzw. autobiografii duchowej16. Nurt literatury filozoficzno-moralno-mistycznej, nie zawsze nasycony elementami autobiograficznymi, rozwija się w Europie od późnej starożytności, poprzez średniowiecze i epoki następne. Znaczą je m.in. takie nazwiska, jak Tertulian, Paweł Apostoł (jego Listy noszą akcenty osobiste), Tomasz à Kempis (Hemerken) ze swym O Naśladowaniu Chrystusa (XV wiek) i wielu innych, a spośród nich tylko niektórzy będą tu wspomniani nieco szerzej.

Filozofowie też należą do wczesnych autorów miejsc wielce zautobiografizowanych swych pism filozoficznych, co w czasach postarożytnych czynił w dużym stopniu Michel de Montaigne w Próbach. Esejach (1580). On też jest jednym z dość wczesnych autorów dziennika już uformowanego gatunkowo. Chodzi o dziennik podróży do Włoch odbytych celem leczenia nerek - Journal de voyage 1580-158117.

Miejsca zautobiografizowane pism filozoficznych dotyczyć mogą metody postępowania badawczego, ściślej - narodzin i rozwoju przyjętej metody filozofowania. Historię taką i dzieje swej metody dochodzenia do prawdy przedstawia twórca racjonalizmu we Francji - René Descartes

14 W. Tatarkiewicz, Historia filozofii, dz. cyt., s. 159.

15 Esencję tej dyskusji stanowi stwierdzenie Lejeune'a, iż autobiografia św. Augustyna jest autobiografią duchową, a pierwszą nowoczesną autobiografią są Wyznania J.J. Rousseau. Zob. recenzja P. Rodaka antologii P. Lejeune'a Wariacje na temat pewnego paktu, „Pamiętnik Literacki” 2002, z. 2, s. 345-352.

16 P. Ricoeur określił ją mianem „literatury konfesyjnej”. W księdze X i XI Wyznań św. Augustyna Ricoeur dostrzegł powiązanie analiz pamięci z analizą czasu. Zob. Pamięć, historia, zapomnienie, przeł. J. Margański, Universitas, Kraków 2009, s. 128.

17 Szersze informacje na ten temat, jak i o historii dziennika, zob. P. Lejeune avec C. Bogaert, Un journal à soi. Histoire d'une pratique, éd. Textuel, Paris 2003. 
w Discours de la méthode 1637. Tu historia ta została przedstawiona od jej narodzin, gdy już ją Descartes sformułował i zrealizował.

Uczestnictwo w rozwoju różnych form wypowiedzi osobistej na przestrzeni czasu jest także udziałem filozofów. W roku 1670 wydane zostają przez członków Port-Royale Myśli Pascala - filozofa, matematyka i fizyka, po trzydziestym roku życia także badacza Pisma Świętego i jansenisty. Nie są to zapisy ujęte w formę dziennika i - jak większość pism filozoficzno-moralno-mistycznych - uogólnione oraz mało spersonalizowane, ale wyrażają osobiste, bardzo intymne przemyślenia swego stosunku do religii, Pisma Świętego, filozofii, świata i Boga. Bardziej niż inne spośród pism o tej tematyce, Myśli Pascala posługują się formami osobowymi i wskazują na piszącego jako podmiot, np. „co do mnie, wyznaję, że...”, „co nas zachęca”, „co mnie przeraża” itd.

W wieku XVIII idealista immanentny i empirysta, duchowny George Berkeley prowadzi w Irlandii dziennik filozoficzny na temat wyłącznie swej pracy, lektury i obserwacji filozoficznej. Znajdują w nim miejsce zapisy pierwszych i późniejszych pomysłów, planów przygotowań większych całości, sposobów wykonania obserwacji filozoficznych itd. Dzienniki filozoficzne Berkeleya ukończone zostały 28 sierpnia 1708 roku. Zapisy nie są prowadzone według dat, lecz ich kolejność wyznacza numeracja zeszytów w liczbie 94 folio ${ }^{18}$.

Za sprawą wspomnianych Wyznań (1776-1778) filozofa natury i pisarza Jeana Jacques'a Rousseau (1712-1778), a nie zapisów Pascala czy Berkeleya, wiek XVIII uznany został za przełomowy w dziejach autobiografii. Wyznania Rousseau są nie tylko najwybitniejszym dziełem sztuki autobiograficznej, ale i wielkim dziełem sztuki pisarskiej. Narracja o historii życia autora, ewokowanego w konwencji wyznań przed Bogiem i historią, z zapewnieniami pełnej szczerości, nie jest mocno zanurzona w historii politycznej swego czasu. Odtwarzając swą przeszłość z pamięci w wieku już zaawansowanym, skupiając uwagę na chwilach szczęśliwych, autor jest świadom pewnych pominięć i obecności elementów zmyślenia: „Pisałem z pamięci, często moja pamięć okazywała się krótka, często przynosiła tylko zarysy wspomnień, a ja uzupełniałem je zmyślonymi szczegółami”19. Rousseau uprawiał także inne formy wypowiedzi

18 Immanentny empiryzm Berkeleya okazuje się przydatny w najnowszej estetyce przestrzeni teatralnej jako „przestrzeni performatywnej”. Zob. na ten temat książka A. Krajewskiej pt. Dramatyczna teoria literatury, Wyd. Nauk. UAM, Poznań 2009, s. 8088. Autorka odwołuje się do filozofii Berkeleya z jego głośnym stwierdzeniem: „Istnieć, to znaczy być postrzeganym".

19 Cytat wybrany za Lejeune'em Les Brouillons de soi, Seuil, Paris 1998. Zob. Wariacje na temat pewnego paktu, dz. cyt., s. 248. Cytat w tłum. Wyznań dokonanym przez T. Żeleńskiego (Boya), Warszawa 1978, s. 218. 
autobiograficzno-filozoficznej, np. Rozmowy z Jeanem Jacques'em Rousseau, Dumania samotnego wędrowca (1776-1778).

Wiek XIX obfitujący w bogactwo nurtów filozoficznych przynosi obszerny dziennik filozofa antycypującego dwudziestowieczny kierunek egzystencjalizmu - Sorena Kierkegaarda. Jego 9-tomowy Dziennik (1869 -1881) jest kluczem do filozofii tego myśliciela, którego życie naznaczone było cierpieniem. Gros zapisów poświęconych jest zagadnieniom filozoficznym, rozważaniu wiary chrześcijańskiej jako aktu ludzkiej egzystencji, cierpieniu i doświadczeniu absurdu z powodu niemożności sprostania przez człowieka jego duchowej namiętności. Natomiast problemy życia osobistego, długiego narzeczeństwa i zerwania $\mathrm{z}$ ukochaną, stanowią małą cząstkę dziennika wydanego po śmierci filozofa.

Choć tytuły niektórych książek filozoficznych brzmią jak tytuły autobiografii, np. Arthura Schopenhauera $W$ poszukiwaniu madrości $\dot{z} y$ $c i a^{20}$, to jednak nie są one autobiografiami, lecz jak w przypadku dzieła Schopenhauera - zbiorem mądrości życiowych wyłożonych za pomocą rad, stwierdzeń, dewiz, aforyzmów itd. Są one zbyt uogólniane, nie odnoszone do bios autora, by szukać w nich elementów autobiograficznych.

U schyłku XIX wieku pojawia się godna uwagi autobiografia wielkiego filozofa, który znacząco oddziałał na postmodernistyczną kulturę wieku następnego i bieg jego historii - Fryderyka Nietzschego Ecce homo (1888). Tekst opowiada tylko niektóre fragmenty życia filozofa; przedstawia ważniejsze prace filozoficzne myśliciela i daje jego autoportret. Pisze go autor pod koniec życia dotkniętego zaburzeniami psychicznymi. Autorzy prac o Nietzschem utrzymują, że choroba psychiczna filozofa nie odbiera nic z wartości naukowych jego myśli ${ }^{21}$. Bogdan Baran określa tę autobiografię jako opis życia, które - zdaniem Nietzschego - znalazło swój niedościgły wyraz w Zaratustrze ${ }^{22}$. Nietzsche, pełen pogardy dla Niemców, mówi o sobie jako o „polskim szlachcicu czystej krwi, bez domieszki choćby kropli krwi niemieckiej"23, o swej boskości, nadludzkości, niezwykłości. Określa się m.in. mianem „kapłana i fizjologa”, „pierwszego immoralisty przebywającego poza dobrem i złem". W sposób przystępny tłumaczy sens niektórych swych dzieł, a w związku z Narodzinami tragedii mówi o sobie jako o „pierwszym filozofie tragicznym”. Patos, hiperbolika stylu, mitomania, odsłaniają posuwającą się chorobę psychiczną. Autoportretowość kompozycji autobiografii Nietzschego pod-

20 A. Schopenhauer, W poszukiwaniu madrości życia. Parerga i Paralipomena, t. I, PWN, Warszawa 2002.

${ }^{21}$ Zob. B. Baran, „Wstęp”, [w:] F. Nietzsche, Ecce homo, przeł. i oprac. B. Baran, Kraków 1996, s. 22.

22 Tamże.

23 Tamże, s. 23. 
kreślają także tytuły wielu jej rozdziałów, np. „Dlaczego jestem taki mądry”, „Dlaczego jestem taki roztropny”, „Dlaczego piszę takie dobre książki" itd.

W dzieje autobiografii filozofów najobficiej wpisał się wiek XX. Znane są autobiografie Bertranda Russella, Michała Bierdiajewa, Karla Jaspersa, Rudolfa Carnapa, Jeana Paula Sartre'a, Paula Ricoeura, Edyty Stein, Simone Weil, Gustawa Maurina, teksty wspomnieniowe i liczne wywiady Barbary Skargi, Leszka Kołakowskiego, Umberta Eco i innych. Spośród wymienionych bliższej uwadze poddana zostanie tylko autobiografia wspomnianego na początku Paula Ricoeura. Wcześniej zaprezentowane zostaną ogólnie autobiografie Russella, Bierdiajewa i Jaspersa.

\section{Część II. Autobiografie XX wieku - rzut oka}

Najobfitszej spośród wymienionych autobiografii XX wieku dostarczył filozof, matematyk, logik, działacz polityczny i społeczny, publicysta i pisarz, laureat Nagrody Nobla w dziedzinie literatury - Bertrand Russell (1872-1970)24 za sprawa 3-tomowej Autobiografii (The Autobiography) (I tom 1872-1914) - 1967; (II tom 1914-1944) 1967; (III tom 1944-1967) 1969 oraz za sprawą autobiografii swego rozwoju filozoficznego Mój rozwój filozoficzny (My Philosophical Developement) (1969). Jego pisarstwo autobiograficzne potwierdza zasadność przyznania mu Nagrody Nobla w roku 1952 głównie za Historie filozofii zachodniej (1945) (The History of Western Philosophy) i literacki sposób wykładu swej filozofii i swych teorii matematyczno-logicznych, mniej za jego powieści.

Lord Bertrand Russell - człowiek renesansu, człowiek instytucja, wnuk premiera Anglii w epoce wiktoriańskiej lorda Johna Russella, odwiedzającego Napoleona na Elbie, wcześnie osierocony, wraz z bratem zaznał miłości rodzinnego domu swych dziadków ze strony ojca. Bardzo wszechstronną osobowość i długie, niezwykle barwne i burzliwe życie, niewolne od skazań więziennych za głoszenie idei pacyfistycznych i wolnomyślnych, oddaje jego 3-tomowa narracja autobiograficzna, w której

${ }^{24}$ Podstawowe informacje o filozofii, logice matematycznej Russella i całościowym dziele jego życia - zob. m.in.: Przewodnik po literaturze filozoficznej XX wieku, dz. cyt., t. I, s. 406-409, 421-425, t. IV, s. 403-420; G. Vesey, P. Foulkes, Filozofia. Stownik encyklopedyczny, wyd. RTW, Warszawa 1997, s. 288-289; S. Blackburn, Oksfordzki stownik filozoficzny, red. J. Woleński, Książka i Wiedza, Warszawa 1994, s. 353-354; E. von Aster, Historia filozofii, PWN, Warszawa 1963, s. 457-459; W. Mackiewicz, Filozofia współczesna $w$ zarysie, wyd. Witmark, Warszawa 1994, s. 103-104 i inne. 
można wyodrębnić kilka dyskursów ${ }^{25}$ (tylko w niektórych z nich wyróżniają się szczególne cechy stylistyczne).

Jednym $\mathrm{z}$ nich jest dyskurs informacji biografii klasycznej, ukazującej $\mathrm{w}$ porządku chronologicznym fakt po fakcie $\mathrm{z}$ życia autobiografa, od dzieciństwa otoczonego miłością babki, nauki pobieranej w domu i w szkołach, poprzez studia matematyczno-fizyczne i filozoficzne w Cambridge, wszechstronną lekturę, prace pisane i wydawane, podjęte i prowadzone wykłady w Anglii i na świecie, podróże, cztery małżeństwa, ojcostwo trojga dzieci, po głęboką starość, naznaczoną aktywnością społeczno-wydawniczą, ostatnim małżeństwem i drugim, tym razem krótkim pobytem w więzieniu wraz z ostatnią żoną.

Kolejny to dyskurs refleksji nad sobą: nad swym rozwojem filozoficznym i logiczno-matematycznym w drodze do osiągnięcia jego perfekcji i doskonałości przyjętych przez siebie wolnomyślnych idei moralnych i polityczno-społecznych, nad zyskami i stratami różnych etapów swego życia w dążeniu do osiągnięcia pełni. Zaduma Russella nad sobą wydaje się zmierzać $\mathrm{w}$ kierunku obiektywizmu, uogólnienia i racjonalizacji, niewolna od autokrytycyzmu, wyznań swych błędów i postępowań niefortunnych oraz pasji poznawczych, cechujących go od wczesnego dzieciństwa, nękanego pytaniem „dlaczego świecą gwiazdy”. Ten dyskurs nasyca trzy tomy autobiografii w wysokim stopniu, a najwyższy poziom racjonalizacji osiąga w Post scriptum, gdzie autor zauważa, że dwie różne sprawy, które długo w jego świadomości istniały oddzielnie, w ostatnich latach stały się jednością. Z jednej strony chciał wiedzieć, czy cokolwiek można poznać, z drugiej - zrobić wszystko, by świat stał się szczęśliwszy. Do roku 1938 poświęcił życie pierwszej sprawie, po tym roku - drugiej. Samoocena i refleksja osobista zyskują nieraz, zwłaszcza w tomie I, charakter analiz psychologicznych, relacji o stanach duszy z ujawnieniem zamiarów samobójczych włącznie, zawodów miłosnych, rozczarowań kontaktami z niektórymi kolegami oraz konsekwencjami aktywności politycznej itd. Osobnej uwagi wymagają przenikliwe wyznania autobiografa na temat młodzieńczych zmagań z problemami poznania i wiary, zanim doprowadziły go one do agnostycyzmu. Poświęcał tym problemom cząstkowe zapisy dziennikowe, prowadzone w różnych okresach młodości. Autor odczuwał „straszliwy ból, gdy poszukując czegoś, co jest poza światem, czegoś przeistoczonego i nieskończonego -

25 Mukoid we wspomnianym artykule wyodrębnia cztery dyskursy w analizowanych autobiografiach pięciu wymienionych wcześniej filozofów, wskazanych według treści (historia życia), nastawienia na odbiorcę, odniesień metatekstualnych, nastawienia na podmiot. Wyodrębnione tu dyskursy uwzględniają te i inne kryteria realizowania kategorii „identité narrative”. 
uszczęśliwiającej wizji Boga"26, musiał skonstatować, że nie można tego znaleźć. Długo, nawet na studiach, nie mógł zrozumieć, by cząsteczki, wchodząc z sobą w relacje, wytwarzały życie.

Następny to dyskurs suchej relacji naukowej, przemieszany z relacją biograficzną. Jego ograniczenie dyktowała świadomość poświęcenia rozwojowi naukowemu osobnej autobiografii. Niemniej, kolejne prace i dzieła z zakresu filozofii opartej na logicznej dedukcji matematycznej i rozgałęzionej teorii typów, filozoficznego uzasadnienia wszystkich geometrii, miejsca wykładów, często ich tematów, znajduja tu swoje rozwinięcie. Nie stwarzając bibliografii swych książek, omawia krótko wiele z nich, od pierwszej poświęconej Filozofii Leibniza (1900), poprzez dzieło życia napisane razem z kolegą ze studiów Alfredem Whiteheadem Principia Mathematica (1910-1913) - trzy tomy, The Analysis of Mind (1921), po ostatnią z tego zakresu, stwarzającą własną wizję filozofii, Historię filozofii zachodniej.

Powyższe typy wypowiedzi, wyznaczane przez ich temat, wzbogaca i pogłębia styl korespondencji, zarówno własnej do adresatów, jak i bardzo licznej korespondencji pisarzy (najwięcej od i do Józefa Conrada, dalej - Bernarda Shawa, Thomasa Eliota, Aldou Huxleya, Henriego Barbussa i innych); filozofów i matematyków (np. z Whiteheadem, Albertem Einsteinem, Rudolfem Carnapem, Johnem Deweyem, Ludwikiem Wittgensteinem i innymi), korespondencja $\mathrm{z}$ kolegami, rodziną i kobietami itd. Wielogłosowość uzyskana także tą drogą i wprowadzenie różnych punktów widzenia uzasadniają i oświetlają wiele problemów osobistych, a także ogólnych. Styl autorski i różne style korespondentów wzbogacają poetyckość wypowiedzi autobiograficznej, wprowadzają sylwiczność i polifonię. Tu znamienne są listy od i do kobiet, nie zawsze żon. Oryginalna poetycka ekspresję Russella zauważyć można np. w liście do Colette z 27 marca 1917 roku: „To rosło we mnie i rosło przez całą niedzielę, a w niej zdawało się przekraczać miarę ludzkich rzeczy"27. W liście z 23 września 1917 roku do Colette przyjmuje metaforę z Ziemi jatowej Eliota: „Cały obszar mojej duszy, gdzie przebywałaś, wydaje się wypalony"28.

Kolejny to dyskurs pamiętnikarski o innych, niezwykle licznych, zwłaszcza ze środowisk uniwersyteckich. Ważniejsze nazwiska zostały tu wymienione $\mathrm{w}$ związku z korespondencją. Dążeniu do obiektywizmu przedstawienia towarzyszy nierzadko emocja: zachwyt lub poczucie roz-

${ }^{26}$ B. Russell, Autobiografia 1872-1914, t. I, przeł. B. Zieliński, „Wstęp” K. Szaniawski, Czytelnik, Warszawa 1996, s. 96-97.

27 Tegoż, Autobiografia 1914-1944, t. II, przeł. A. Podzielna, Czytelnik, Warszawa 1998, s. 101.

28 Tamże. 
czarowania. Dla nas Polaków miłe są pozytywne charakterystyki Conrada, którego poprosił Russell na ojca chrzestnego swego pierwszego syna oraz takież wzmianki o filozofii Leona Chwistka i stwierdzenie (może żartobliwe), że wśród sześciu czytelników jego Principia Mathematica trzech było Polakami.

Marginalnie pojawiają się informacje autotematyczne, tyczące kolejności załączanej korespondencji i recenzji czy innych krótszych prac oraz zdań o charakterze profetycznym. Tym ostatnim towarzyszą czasowniki typu „wydaje mi się” (co do przewidywania wkroczenia świata w okres ciemności), „przewidziałem”, „przepowiedziałem” (dotyczy zbrojeń nuklearnych i dominacji dwu mocarstw po drugiej wojnie światowej) itd.

Wielogłosowa, sylwiczna, długa autobiografia Russella znajduje dopełnienie w opowieści o rozwoju naukowym tego myśliciela - Mój rozwój naukowy. Autor poprzedza prezentację swego rozwoju naukowego wskazaniem na czynniki go kształtujące, a to: bogate oczytanie filozoficzne i kulturowe, wpływ ludzi, których w różnych okresach życia spotykał oraz własne zainteresowania problemami, pasjonującymi filozofa dłużej lub krócej. Pragnienie wiedzy oraz zrozumienia tego, ile naprawdę wiemy, a także stopnia pewności towarzyszącej tej wiedzy cechowały Russella od dziecka. Nie pragnąc stworzyć określonego systemu filozoficznego, filozof ten zainteresowany był wielorakością sensów przedmiotów, nie istotą rzeczy. Różnorodność zainteresowań połączyła w nim role matematyka, logika i filozofa analitycznego, nie fenomenologicznego bynajmniej. Ta wielość ról przyjętych w myśleniu i pisaniu prowadziła niejednokrotnie do sprzeczności i zmian własnych poglądów: precyzja logiczna kłóci się z niejednoznacznością i pluralizmem w filozofii.

Zarówno 3-tomowa autobiografia całości życia i dokonań, jak i autobiografia historii trudu stworzenia filozoficznych i logicznych podstaw matematyki Russella osadzone są mocno w tradycji. Swej krytycznej lekturze dzieł wielkich filozofów (np. Leibniza, Berkeleya, Hegla, Kanta i innych) autor poświęca wiele uwagi. Jednocześnie dokonania Russella tkwią mocno w aktualnym czasie dziania się jego rozwoju naukowego. Żaden godny uwagi fakt naukowy nie uchodzi uwadze autora i ma wpływ na jego teorie. Podkreśla np. duży wpływ na siebie atomizmu logicznego Giovanniego Peana, krytyki swego pozytywizmu logicznego przez Wittgensteina, wpływ filozofii referencji Gottloba Fregego na swą koncepcję referencji, a nade wszystko dzieła Einsteina. Po lekturze jego dzieł pierwsze swe prace na temat geometrii wydały mu się nierozsadne. Pisze m.in.: „Rewolucja Einsteina zmiotła wszystko”29. Ostatni rozdział

29 B. Russell, Mój rozwój filozoficzny, przeł. A. Krahelska, Cz. Znamierowska, PWN, Warszawa 1959, s. 28. 
opowieści o własnym rozwoju naukowym Russell poświęcił polemikom z głównymi adwersarzami i krytykami swych dzieł, m.in. z Wittgensteinem, G.F. Warnockiem, P.F. Strawsonem i innymi. Filozofia Russella odrzuca pewność doświadczenia i odsłania mechanizmy myślenia.

Obydwie autobiografie filozofa są wiernymi realizacjami modelu autobiografii klasycznej, ewoluującej w kierunku sylwiczności, typowej dla nowszych czasów. Stanowią też osiągnięcia sztuki pisarskiej, docenionej w innych dziełach niż autobiograficzne - już w roku 1952 przez Instytut Noblowski. Łatwość, metaforyczność i elegancja pióra idzie w parze ze zdolnością wyłożenia w sposób prosty trudnych zagadnień logiczno-matematycznych. Ujmujący w swej prostocie jest np. wykład klas, typów i relacji, z objaśnieniem przyjętych symboli w Principia Mathematica dla każdej z tych kategorii. Skomplikowana, bogata, wszechstronna tożsamość autora wyłaniająca się z kart tych pism autobiograficznych jest określana przez autorów piszących o Russellu różnymi metaforami, m.in. piły tarczowej, trącej w przeciwnych kierunkach (zob. okładki autobiografii).

Russell daleki był w swych autobiografiach od rozważań teoretycznych na temat uprawianego gatunku. Podobnie dalecy od takich poczynań byli dwaj następni filozofowie dwudziestowieczni - autorzy autobiografii mieniący się filozofami niezawodowymi: Bierdiajew i Jaspers.

Pierwszy (1872-1948) Mikołaj Bierdiajew ${ }^{30}$ - arystokrata rosyjski z korzeniami francuskimi po matce, ukazem Lenina z roku 1922 wydalony z Rosji za działalność antykomunistyczną, choć uważał się okresowo za socjaldemokratę, spędził ostatnich dwadzieścia sześć lat na Zachodzie: krótko w Berlinie, a głównie we Francji, współtworząc życie umysłowe Paryża tego czasu. Jego Autobiografia filozoficzna (Samopoznanije. Opyt filosofiskoj autobiografii 1949) jest raczej autoportretem złożonej osobowości i bogatego życia intelektualno-duchowego jej autora. W wielu powracających wielokrotnie samookreśleniach mówi o sobie jako nie o „filozofie szkoły”, choć przeszedł szkołę Kanta, rozróżniając świat zjawisk i rzeczy samych w sobie, porządek przyrody i porządek wolności. $\mathrm{W}$ perspektywie negatywnej samookreśleń pojawia się też przymiotnik „nieprofesjonalny” (filozof), „pozostający na uboczu”31 i rzeczowniki „indywidualista” i „rewolucjonista” w młodości. Swoją filozofię najczęściej zalicza do egzystencjalizmu: „Jestem skłonny określać siebie jako meta-

${ }^{30}$ Informacje podstawowe na temat tego filozofa por. np. Przewodnik po literaturze filozoficznej XX wieku, dz. cyt., t. II, s. 31-42; G. Vesey, P. Foulkes, Stownik encyklopedyczny..., dz. cyt., s. 48; W. Mackiewicz, Filozofia wspótczesna $w$ zarysie, dz. cyt., s. 167; T. Bartoś, Kościót a teologia dwudziestego wieku, „Przegląd Powszechny” 2009, nr 4 i inne. 31 M. Bierdiajew, Autobiografia filozoficzna, przeł. M. Dwernicki, Kęty 2002, s. 83. 
fizyka, filozofa egzystencjalnego, historiozofa, moralistę"32. Za główny jej cel uważa Bierdiajew poznanie, które według niego dokonuje się nie tylko rozumem, ale i siłami duchowymi i emocjami. Celem poznania zaś jest według autora Bóg, a jego tajemnicę upatruje w bogoczłowieczeństwie. Chrześcijaństwo swe widzi jako chrystologiczne, w odróżnieniu od chrześcijaństwa dostosowanego. Dokonując swej autocharakterystyki według cech rosyjskości, czasem przeciwstawionych tkwiącej $\mathrm{w}$ nim francuskości, następnie - właściwości typowych dla arystokracji w ogóle, dostrzega je u siebie w uznaniu prymatu filozofii moralności. Wiele razy powołuje się na rosyjskie korzenie swej myśli, wskazując w pierwszym rzędzie na nazwisko Lwa Szestowa, Włodzimierza Sołowiowa, następnie Fiodora Dostojewskiego, Lwa Tołstoja i innych. Jednocześnie maluje dokładny obraz życia umysłowego Paryża czasu lat dwudziestych i trzydziestych XX wieku, które sam współtworzył, pracując z takimi intelektualistami francuskimi orientacji chrześcijańskiej, jak np. Emanuel Mounier, Charles du Boss, Jacques Maritain, Charles Péguy, Léon Bloy. Obraz ten może konkurować $\mathrm{z}$ wieloma innymi obrazami przedstawionymi w tekstach autobiograficznych pisarzy francuskich, jak: André Gide, du Boss, Paul Léautaud. Podkreślając również swój arystokratyzm (np. wyniosłość), nie ukrywa braku sympatii do tej klasy. Swą duchowość (stale powtarzał: „Wyznaje religię ducha” 33 , „Moja filozofia jest filozofią ducha") ustawiał w relacji do cerkwi, liturgii, która go nie przekonywała, i kościoła w imię zasady: „W moim życiu religijnym wyszedłem od wolności i doszedłem do wolności" 34 . Omawiając swą pracę filozoficzną [np. książki Filozofia swobodnego ducha (1927), Cinq méditations sur l'existence (1936), Russkaja ideja... (1946), Problemy komunizmu (1937)], podnosi uznanie, jakim cieszył się w świecie, o czym świadczyły przekłady, wówczas na czternaście języków.

Drugim z wymienionych „filozofów niezawodowych” - autobiografów XX wieku - jest Karl Jaspers (1883-1969)35, również egzystencjalista religijny, inaczej niż Bierdiajew - protestant. Jego Autobiografia filozoficzna (1953) wbrew tytułowi, w początkowej części jest bardziej autobiografią całości życia i więcej niż o filozofii mówi o swej pierwszej profesji medycynie, ściślej - psychiatrii. Tytuł z przymiotnikiem „filozoficzna”

32 Tamże, s. 272.

33 Tamże, s. 152

34 Tamże, s. 156

${ }^{35} \mathrm{Na}$ temat K. Jaspersa - zob. m.in.: Przewodnik po literaturze filozoficznej XX wie$k u$, dz. cyt., t. I, s. 193-214, t. II, s. 204-227; W. Tatarkiewicz, Historia filozofii, t. III: Filozofia XIX wieku i wspótczesna, PWN, Warszawa 1958, s. 90, 270, 478-479, 486, 526, opracowania P. Ricoeura i M. Dufrenne’a - zob. przyp. 39; R. Rudziński, Jaspers, Wiedza Powszechna, Warszawa 1978. 
nadał autor ze względu na motyw jej napisania: namowa prof. Paula A. Schilippa, by opowiedział, co sprowadziło go na drogę filozofii. Jaspers był zainteresowany filozofią od wczesnych lat, ale podjął inne studia. Po trzech semestrach prawa zaczął studiować medycynę, interesując się także sztuką, teatrem, poezją, grafologią. Zostawszy docentem psychiatrii, pracował $\mathrm{w}$ klinice psychopatologii w Heidelbergu, współpracując m.in. z Leopoldem Rankem. W jego pracach z zakresu psychiatrii (interesowały go m.in. takie tematy, jak nastrój, przestępczość, złudzenia) przewodnikami byli filozofowie, zwłaszcza Husserl, którego fenomenologię przyjął jako metodę swego myślenia psychiatrycznego. Na własną prośbę został okresowo przeniesiony do katedry filozoficznej na uniwersytecie w Heidelbergu, a jako profesor filozofii podjął tam pracę w roku 1921 i pozostał do roku 1937. Wyznając atawistyczne umiłowanie filozofii, pisał: „Medycynę i psychologię obrałem z pobudek filozoficznych. Obawa przed wielkością zadania powstrzymywała mnie w życiu przed tym, by uczynić sobie z filozofii zawód"36. Książka Psychologia światopogladów, pojmująca psychologię egzystencjalnie, utorowała mu drogę do filozofii, mimo złego przyjęcia Jaspersa przez krąg pracujących tam filozofów holenderskich: Wilhelma Windelbanda i Heinricha Rickerta. Znaczny wpływ na swą filozofię przypisuje Maxowi Weberowi. Autobiografia filozoficzna Jaspersa pełna jest rozwiniętych przedstawień faktów biograficznych i przeżyć. Jaspers - lekarz - czuł się „młodzikiem” - jak go określał wrogi mu Rickert - wśród dostojnych filozofów uniwersyteckich. Rickert, mówiący źle o Jaspersie na wykładach, przypisywał karierę filozoficzną Jaspersa Weberowi, który w jednym z przypisów do swych prac podkreślał zasługi Jaspersa w logiczności myślenia. Opis faktów życiowych w autobiografii Jaspersa uwikłany jest bardzo silnie w interakcje międzyludzkie, wydobywa ich psychologiczne tło. Obok wspomnianych filozofów warto tu wskazać na kontakty z Martinem Heideggerem, którego autor cenił najbardziej spośród „klanu współczesnych filozofów”. Jaspers nie podejmuje krytyki filozofii Heideggera, z uznaniem pisze o jego Sein und Zeit, broni go nawet przed zarzutami prohitleryzmu, lecz zarysowuje tylko wspomnienia ze spotkań, do przedstawienia tego, o „czym się myślało, co między nami zaszło” 37 . Ostatni ich kontakt miał miejsce w roku 1964. Obydwaj chcieli pojednania, ale do tego nie doszło. Brak było między nimi napięcia i sympatii, królowała obcość.

Mocno akcentowane przeżycia wewnętrzne w autobiografii Jaspersa dotyczą też w dużym stopniu trudnej drogi do filozofii i związane są

${ }^{36}$ K. Jaspers, Autobiografia filozoficzna, przeł. S. Tyrowicz, Wyd. Comer, Toruń 1993, s. 28.

37 Tamże, s. 112. 
z poczuciem swej obcości wśród filozofów zawodowych, osamotnienia, pogłębianego także przez słaby stan zdrowia. Potem, po dojściu do władzy Hitlera, dołączyły się represje ze strony władzy z powodu małżeństwa z Żydówką. Pozbawiany honorów uniwersyteckich musiał w 1937 roku opuścić Heidelberg. Wyzwolone tym zainteresowania polityką (rozdział VIII autobiografii nosi tytuł „Myśl polityczna”) podbudowane były przekonaniem, że filozof nie może nie interesować się polityką. Potwierdzaja to wszystkie przedstawione tu autobiografie filozofów dwudziestowiecznych. Z goryczą rozważa Jaspers ideę niemieckości w historii, relacje niemieckości do bolszewizmu, problemy socjaldemokracji niemieckiej i hitleryzmu, rolę aliantów w wojnie itd.

Do Heidelbergu wraca Jaspers w roku 1945, by trzy lata później przenieść się na stałe do Bazylei. Ostatnie rozdziały autobiografii poświęcone są jego filozofii. W skrócie koncentruje swe myśli wokół kluczowych problemów egzystencjalizmu z nachyleniem mistycznym i personalnym, zwłaszcza takich, jak sytuacja graniczna, relacje egzystencjalizmu i teologii, spotkania człowieka z Bogiem, śmierci, sensu własnej pracy, uczestnictwa w całokształcie życia itd. Wskazuje na swe książki, np. dwa tomy Philosophie (1932) czy Filozofię egzystencji (tłum. pol. 1990).

\section{Część III. Autobiografia Paula Ricoeura}

Dużo ciepłych słów poświęca postaci Jaspersa w swej autobiografii Paul Ricoeur 38 , który poznał jego filozofię $w$ niewoli na Pomorzu za sprawą Mikela Dufrenne'a. Razem z Dufrenne'em napisali książkę o tym filozofie, a następnie pracę o Jaspersie i Marcelu ${ }^{39}$. Autobiographie intellectuelle Ricoeura stanowi oryginalną, francuską wersję eseju, który otwiera angielski zbiór pt. Philosophy of Paul Ricoeur ${ }^{40}$, wydany również w wersji francuskiej w 1995 roku. Paul Ricoeur (1913-2005), filozof zawodowy, skupiony na jednej dyscyplinie naukowej, ale „poddający” refleksji filozoficznej szerokie spectrum dyscyplin pokrewnych, głównie teorii literatury, był - jak już wspomniano na początku - filozofem hermeneutą, fenomenologiem hermeneutycznym i filozofem człowieka.

${ }^{38}$ Podstawowe wiadomości o P. Ricoeurze i jego filozofii - por. wspomniana książka M. Drwięgi, wymienione artykuły Z. Mitosek i K. Rosner z tegoż numeru „Tekstów Drugich”, słowniki filozoficzne podane przy trzech powyższych filozofach i inne prace.

${ }^{39}$ P. Ricoeur, M. Dufrenne, Karl Jaspers et la philosophie de l'existence, Temps Présent, Paris 1947; Gabriel Marcel et Karl Jaspers. Philosophie du paradoxe, Paris 1948.

${ }^{40}$ The Philosophy of Paul Ricoeur, ed. L.E. Hahn, Open Court Chicago-Lasalle, Illinois 1995 . 
Historię swego rozwoju intelektualnego poprzedza Ricoeur refleksją autotematyczną. Autobiografię zalicza autor do pism na temat autozrozumienia. Przymiotnik „intelektualny” anonsuje, że esej położy nacisk na problemy rozwoju filozoficznego, a fakty biograficzne ograniczone zostaną tylko do tych, które pozwolą oświetlić ten rozwój. Po wyjaśnieniach zasadności użytego terminu następują dywagacje definicyjne, ograniczone zrazu do stwierdzenia, że autobiografia jest opowieścią życia i jak każde dzieło narracyjne jest selektywna. $\mathrm{Z}$ tego tytułu każdy autobiograf używa wybiegów. (Pamiętamy wcześniejszą szeroką, antropologiczną definicję z Temps et récit.) Poza tym autobiografia jest dziełem literackim. Opiera się na rozdźwięku między retrospektywnym punktem widzenia aktu pisania wpisanego w życie oraz upływem codzienności życia. Ten rozdźwięk odróżnia autobiografię od dziennika. Autobiografia w końcu zakłada tożsamość postaci głównej opowieści, która jest sobą i jednocześnie narratorem mówiącym o sobie ,ja”. Ta węższa definicja autobiografii Ricoeura zawiera zatem wszystkie składniki sławnej definicji Lejeune'a. Jej novum może stanowić zwrócenie uwagi na „pokrętność" (stosowanie wybiegów) („l'autobiographie est biaissée”) w wyborze wydarzeń poddanych narracji. Autor podkreśla niedoskonałość rekonstrukcji rozwoju filozoficznego własnego ,ja” w porównaniu z rekonstrukcją biegu jego życia, niemniej jednak ten trud podejmuje.

Zgodnie $\mathrm{z}$ wyjaśnieniem tytułu Ricoeur ogranicza informacje biograficzne, wskazując na niektóre i nie podaje ich zawsze w porządku chronologicznym. Z kart jego autobiografii nie poznamy szczegółów z życia filozofa ani bogactwa przeżyć, ograniczonych do wzmianek o żałobie z powodu samobójstwa czwartego syna i śmierci przyjaciela Eliadego oraz do zachwytu nad postacią filozofa czeskiego Jana Patoczki. Pośrednio, a na końcu - bezpośrednio, eksponowane jest uczucie stanowiące esencję ipse jego tożsamości - rozterka $\mathrm{z}$ powodu rozbieżności istoty filozofii autora i jego tkwienia $w$ ideach biblijnych. Ricoeur nie omawia wszystkich swoich prac, a tym bardziej nie podaje ich bibliografii, ale wskazuje na niektóre, zwłaszcza z lat siedemdziesiątych i osiemdziesiątych wchłonięte nieraz przez większe całości wydawnicze.

Prezentację własnego rozwoju filozoficznego Ricoeur rozpoczyna od siedemnastego roku życia, znaczonego pobieraniem nauki w klasie filozoficznej liceum w Rennes, a następnie na uniwersytecie w Rennes. Preceptorami byli filozofowie formacji neotomistycznej, zainteresowani jednak psychologia Freuda. Główny nauczyciel - Roland Dalbier - pierwszy we Francji pisał właśnie o tym psychoanalityku. Zainteresowany myślą Kantowską i francuskim modernizmem filozoficznym Ricoeur już u początków swej drogi naukowej nie umiał identyfikować się z filozofią 
Montaigne'a, Rousseau, Pascala. Uczestniczył w ruchu młodzieży protestanckiej (protestantyzm odziedziczył po domu dziadków „paternels”, wychowujących dwójkę wcześnie osieroconych wnuków). Studiował też w tym czasie teologię protestanta Karla Bartha, a potem innych. Kolejne szczeble studiów filozoficznych po obronie maîtrise na uniwersytecie w Rennes w roku 1934 otwierała Sorbona. Niepowodzeniem skończył się egzamin do L'Ecole Normale Supérieure. Ricoeur chłonie wiedzę przekazywaną przez autorytety naukowe (np. Léon Robin, Léon Brunschwieg), wzbogaca ja kontaktami z wybitnymi filozofami (np. udział w „vendredi” u Gabriela Marcela, w redakcji „L’Esprit” skupionej wokół Emmanuela Mouniera). Kontakty te wzbudzaja zainteresowania innymi filozofami, np. Maritainem, Maxem Schellerem. Obok tych fluidów religijno-egzystencjalistycznych otwarty jest na własne lektury filozoficzne od Bergsona po Brunschwiega. Krytycznie chłonie Kanta i Heideggera.

Referowanie ważniejszych dla autora własnych jego prac otwiera informacja o napisaniu wstępu do Idei... Husserla, kwestionującego przekonanie panujące od Descartes’a o przejrzystości i apodyktyczności „,cogito". O studiach nad Husserlem wspomina Ricoeur wielokrotnie, tym bardziej, że ukoronował je tłumaczeniem niektórych jego prac, np. Idées Directrices. Ale nie wspomina o swych wyprawach do archiwum Husserla do Louvain. Następnie omawia czołowe kategorie książki Symbolique du mal (1960, Symbolika zła), takie jak symbol i mit, określane także mianem figur. Do tej książki wraca Ricoeur wielokrotnie, porównując ją z innymi, które napisze. Wśród studiowanych filozofów we wczesnym okresie swej aktywności pojawia się także nazwisko Romana Ingardena, obok częściej wymienianego Maurice'a Merleau-Ponty'ego i innych.

Po wydaniu Symbolique du mal filozof wkracza w okres polemik. Nie tylko kontynuuje tę podjętą wcześniej z egzystencjalizmem, ale i ze strukturalizmem oraz z tymi filozofiami, w których centrum spoczywa podmiot. W pierwszym rzędzie wskazuje on na francuskich uczniów Heideggera zafascynowanych jego Sein und Zeit - dziełem, jak pisze Ricoeur, „mniej lub więcej egzystencjalistycznym”. Można się domyślić, że będą oni adresatami tych polemik, ale ich nie wymienia. Otwarty na wszystko co nowe i wartościowe w kulturze odnotowuje nazwiska twórców strukturalizmu we Francji - od Emila Benveniste'a, Claude'a Lévi-Straussa, Ferdynanda de Saussure'a, poprzez semiologizujących Barthes'a czy Algirdasa Greimasa. Dokonuje dalej przeglądu nowych prądów myślenia w latach sześćdziesiątych i siedemdziesiątych dwudziestego wieku. Swój rozwój filozoficzny bowiem ukazuje Ricoeur na ich tle głęboko zanurzonym w tradycji filozoficznej, przynajmniej od czasów św. Augustyna. Bardziej ogólnie wspomina przedstawicieli modnej wów- 
czas wśród inteligencji we Francji szkoły marksistowskiej z Louis Althusserem na czele oraz pionierów nowszych nurtów psychoanalizy, zwłaszcza Jacques’a Lacana, na którego seminaria uczęszczał. Spośród wymienionych kierunków najbliższy okazał się autorowi strukturalizm, który charakteryzuje i wraca do różnych jego składników w późniejszych pracach. Jednocześnie podejmuje swoją koncepcję podmiotu myślącego i działającego w orbicie analiz strukturalnych. Ricoeur stale jednak wraca do zagadnień symbolu i podejmuje jego zredefiniowanie, wchodząc głębiej w lekturę psychoanalityczną Freuda i Hegla z Phénomenologie de l'és-prit. Przyznaje, że w jego rozważaniach na temat „konfliktu interpretacyjnego", odwołującego się do nauk Freuda, Francuzi dostrzegli brak uwzględnienia teorii psychoanalitycznych Lacana, choć jak dodaje - znał go także z seminariów. Ricoeur widział psychoanalizę Freuda w wielu podejrzeniach hermeneutyki, znaczonych nazwiskami Feuerbacha, Marksa, Nietzschego i innych. Drugą stroną konfliktu interpretacyjnego (Conflit des interprétations 1969) był wedle autobiografa strukturalizm w wersji semiologicznej. Wspomniana ostatnia książka hermeneutyczna ujmująca referowane powyżej problemy uwydatnia figure „Cogito walczącego i zranionego”. Opis swych podróży myśli poprzez nurty filozoficzne, antropologiczne i teoretyczno-literackie XX wieku obrazuje Ricoeur figurą walki. Odnotowując pierwszą z nich, debatę ze strukturalizmem, wyodrębnia trzy jej fronty, a punktem wyjścia tej walki była teoria dyskursu. W dyskursie wyodrębnia bowiem filozof królestwo znaku (Cogito zranione), jego relacji ze światem oraz istoty referencji w te relacje uwikłanej.

$\mathrm{Na}$ marginesie obrazu swych podróży intelektualnych odnotowuje Ricoeur prace ważne dla jego życia wewnętrznego, związane z różnymi postaciami dyskursu biblijnego, wyrażającego różne imiona Boga, jak m.in. wstępy do dzieł Rudolfa Bultmanna, Yvesa Bonnefoya, J. Moltmanna, własne prace, np. Nommer Dieu, Exégèsis i inne.

Do tych danych dołącza autobiograf przegląd ważnych faktów życiowych od roku 1935, kiedy to osiągnął agregację z filozofii i ożenił się z koleżanką ze studiów, a następnie przeżył żałobę po śmierci wychowujących go dziadków. Studiując w Rennes, pracował w liceum w Saint-Brieu, Lorient i Colmar, a wśród miejsc swego zamieszkania i pracy wymienia Chambon-sur Lignon. Po powrocie z niewoli pracował w Collège Cévenol. W roku 1948 został mianowany profesorem filozofii na uniwersytecie w Strassburgu, a w roku 1956 - profesorem Sorbony. Wśród różnych zajęć na Sorbonie wymienia m.in. dyrekturę seminarium, dzieloną z Jacques'em Derridą, współpracę z „L’Esprit”, gdzie w roku 1964 drukował m.in. artykuł pt. Faire l'université na temat tworzenia 
uniwersytetu w Nanterre, skupiającego głównie młodzież niezadowoloną $\mathrm{z}$ istniejącego porządku. Był tam dziekanem do roku 1970, kiedy to rozpoczął wykłady na uniwersytecie w Louvain w Belgii, by po trzech latach wrócić do Nanterre i opublikować książkę, której poświęca wiele miejsca na kartach swej autobiografii, pt. La Métaphore vive (1975).

Metafora, której złożył hołd już Arystoteles w Poetyce oraz Retoryce, jest, zdaniem autora, kamieniem węgielnym kreacji artystycznej i w sposób ukryty łączy się z innymi formami kreacji uporządkowanej zarówno semantycznie, jak i w konstrukcji fabuły, narracji czy podmiotu. W tej ostatniej kwestii ważny był problem podwójnego sensu słów. W studiach refiguracyjnych słów i ich relacji do referencji dostrzegł Ricoeur w swej autobiografii, że w jego omawianych pracach brakło ogniwa pośredniego, którym jest akt lektury. Bowiem to sam czytelnik odnosi się „do” czegoś. Autor eksponuje dalej istotę swej koncepcji hermeneutyki za pomocą teorii tekstu jako przedmiotu działań hermeneutycznych: wyjaśniania i rozumienia (dodajmy - by interpretować). Esej z 1970 roku Czym jest tekst. Wyjaśnienie i rozumienie, mówi o tym, że ukryty konflikt hermeneutyczny między tymi działaniami rozwiązuje interpretacja. Nawiązując do osiągnięć Wilhelma Diltheya z roku 1900 L'origine de l'herméneutique, Ricoeur nie ustawia pojęć wyjaśniania i rozumienia w sposób alternatywny, lecz dewizą czyni „sztukę hermeneutycznej interpretacji”, co w uproszczeniu oznacza - „wyjaśnianie więcej” dla „rozumienia lepszego”. Zagadnienia te czyni przedmiotem wykładów w Louvain, obok tych, tyczących semantyki działania i koncepcji dyskursu.

Równolegle do wykładów z fenomenologii i hermeneutyki w Belgii i we Francji Ricoeur prowadzi regularnie wykłady, od 1970 roku przez kilka tygodni w roku w Chicago, z zakresu filozofii analitycznej, traktowanej jako przeciwieństwo wyżej wspomnianych nurtów filozoficznych.

W kręgu zainteresowań intelektualnych Ricoeura pozostają także artykuły polityczne. Na jeden z nich, dotyczący tworzenia uniwersytetu w Nanterre, zwrócił Ricoeur uwagę wcześniej. Niektóre związane sa z wydarzeniami w Budapeszcie. Pisze też szkice o filozofii politycznej Erica Weila i innych. Każdy z trzech omawianych tu autobiografów filozofów XX wieku angażował się politycznie i nie szczędził miejsca w swych pracach na pisanie o problemach politycznych.

Sprawozdanie z przewodu myślowego trzech tomów Temps et récit (1983-1985) poprzedza przelot myślowy nad lekturami Husserla i Hansa Georga Gadamera, głównie celem przyjrzenia się spuściźnie fenomenologii Husserlowskiej i hermeneutyce post-Heideggerowskiej, co uczynił autor w Du texte à l'action. Essais d'herméneutique II (1986), A l'école de 
la phénoménologie (1986). Podstawą zakwestionowania przez hermeneutykę subiektywizmu fenomenologii jest teoria tekstu. Ricoeur przebiega myśli ważniejszych swych prac i wcześniejszych książek, ustala związki między nimi. Książki De l'interprétation. Essais sur Freud (1965) i Métaphore vive traktuje jako jeden ciąg myśli rozwiniętych w różnych kierunkach w trzech tomach dzieła Philosophie et la volonté (1960-1986). Przesłanki tych pomysłów dostrzegł w opublikowanej już w roku 1955 L'Histoire et verité, rozwinięte następnie we wspomnianej wyżej pracy Du texte à l'action... Omawiając kolejne swe artykuły i książki, odnotowuje Ricoeur niektóre ich tematy jako przedmioty wykładów na różnych uczelniach. Wszedłszy w polemikę ze strukturalizmem porównuje strukturalizm francuski, zwrócony w kierunku krytyki literackiej, ze strukturalizmem anglojęzycznym, związanym $\mathrm{z}$ poznaniem historycznym. Za sprawą swych językoznawczych źródeł (wkład de Saussure’a) strukturalizm francuski nie pytał o wydarzenia pozajęzykowe, o prawdę wydarzeń. Jego modelem pozostało opowiadanie fikcjonalne, a kategoria „l'effet du réel” Barthes'a odczytywana była jako strategia dyskursu, którego opis daje iluzję referencjalności. Stąd zainteresowanie Ricoeura nadaniem narratywizmowi francuskiemu ciężaru filozofii analitycznej. Kwestią récit zajął się też autobiograf ze względu na zainteresowania egzegezą biblijną, czemu dał wyraz wcześniej w kilku swych pracach. Nie bez znaczenia były też wnioski, do jakich dochodził $\mathrm{w}$ toku swych wykładów i seminariów. O pracy dydaktycznej mówi bardzo ciepło; przynosiła ona filozofowi dużo satysfakcji. W ujęciu problematyki czasu mistrzem niezastąpionym pozostał św. Augustyn, niezależnie od podziwu dla Husserla i Heideggera.

Trzy tomy Temps et récit omawia Ricoeur pod kątem aporii czasu, niemożności ujęcia go równocześnie w wielu aspektach: fizycznym, psychologicznym, kosmologicznym, fenomenologicznym; aporii wokół struktury teraźniejszości, wywiedzenia czasu ze świata i z ducha; roli inwencji semantycznej i inwencji twórczej. Zagadnienie dialektyki wyjaśnienia i zrozumienia, zarówno $\mathrm{w}$ opowiadaniu fikcjonalnym, jak i historiozoficznym, stanowi nić przewodnią omówień trzech tomów Temps et récit. Osobnej uwadze autora podlega tom trzeci dzieła, w którym - jak mówi na pierwszy plan wraca stary problem referencji dyskursu, ,jedna z ważniejszych stawek polemiki ze strukturalizmem francuskim" (s. 73), problem, który już poruszył Ricoeur w Metaforze żywej w związku z rozróżnieniem „śladu”, sensu Fregego i referencji wyrażeń metaforycznych. Stanowiskiem Ricoeura z momentu pisania autobiografii jest przyjęcie rezerwy wobec propozycji mediacji lekturowej między przedmiotem wyrażonym w ekspresji słownej i nią samą. Ideę referencji Ricoeur 
proponuje zastąpić ideą „refiguracji” zarówno w teorii metafory, jak i w opowiadaniu. Refrencja ma inny sens w opowiadaniu fikcyjnym, inny w opowiadaniu historycznym. Dla tego drugiego typu récit Ricoeur stworzył kategorię „identité narrative” (patrz przypis 4). Wyjaśniając sens niektórych swych dzieł, autobiograf dokonuje małych korekt stworzonych przez siebie teorii.

Temps et récit ukończył Ricoeur w roku 1984 wraz z otrzymaniem zaproszenia do Edynburga na wykłady na temat narracji pierwszoosobowej. Zastanawiając się nad tematem zaproszenia, pyta sam siebie, czy nie chodziło tu o problemy medytacji i autobiografii. Chwiejność znaczeń „identité narrative” podmiotu opowiadania polega na pomieszaniu jego „identité-mêmeté” z „identité-ipseité”. Dopowiedzenia te z wyjaśnieniami powtórnymi kategorii „identité narrative” znalazły się w przygotowanych wykładach do Edynburga, wydanych jako Gifford Lectures 1986. $\mathrm{W}$ omówieniach Temps et récit Ricoeur opuszcza problem trzech mimesis, choć tłumaczy kluczowe ich myśli; III mimesis to przecież problematyka referencji. Również pomija omówienie książki już wydanej przed napisaniem autobiografii Soi-même comme un autre (1990), ale wielokrotnie podnosi problemy etyczne, skoncentrowane w słowach Chrystusa, które są przedmiotem głównej uwagi tej książki. Wstęp do niej jest natomiast przedmiotem wyjaśnień. Pod koniec autobiografii Ricoeur dostarcza kilku informacji biograficznych, wywołujących silne przeżycia autora, o których była już mowa. O pierwszym (samobójstwie czwartego syna) autor pisze: „Jak mógłbym nie mówić o tym dramacie, nawet w autobiografii intelektualnej?" (s. 79). W ramach rozważań etycznych powraca Ricoeur do zagadnień politycznych, pochylając się bliżej nad relacją tych dwu kwestii do siebie.

Zwroty autotematyczne na temat istoty autobiografii nie tylko otwierają autobiografię Ricoeura, ale też ją zamykają. Filozof nie żałuje, że nie daje ona odpowiedzi na podstawowe pytanie gatunku o powinność filozofa, by powiedział, skąd pochodzi głos świadomości; czy od innej osoby niż ta, którą mógł ukazać jako „ipseité”, czy od jej przodków, a może od umarłego lub żyjącego Boga, ale też nieobecnego $\mathrm{w}$ ukazanej historii swego życia? Nękanie filozofa tym pytaniem i świadomość niemożności dania odpowiedzi na relację treści jego filozofii i treści swych przekonań światopoglądowych, ich niezgodności z sobą są ostateczną odmiennością (altérité) jego „ipseité” oświetlonej w autobiografii filozoficznej. Ukazanie tej aporii oraz aporii „innego”, obecnego nie tylko w dyskursie filozoficznym, ale i w czasie nam danym, uważa Ricoeur za podstawową kwestię poruszoną we "Wstępie” do książki Soi-même comme un autre. Jest to również problem relacji filozofii i niefilozofii. Inaczej: filozofii bez absolu- 
tu i jego wiary biblijnej, żywionej bardziej egzegezą Biblii niż teologią. Temu problemowi poświęca książkę Liebe und Gerechtigkeit. Amour et justice (Tübingen 1990).

Spośród omówionych czterech autobiografii filozofów dwudziestowiecznych trzy z nich dają wyraz zainteresowaniom filozofów i ich światopoglądom bliskim problematyce religijnej. Tylko B. Russell filozoficzne podstawy logiki i matematyki prezentuje jakby niezależnie od swych odejść od młodzieńczych przekonań bliskich metafizyce. 